\title{
Association of Connexin 32 with Prostate Volume and PSA Level in Prostatic Adenocarcinoma and Adenomyomatous Hyperplasia
}

\section{Prostat Adenokarsinomu ve Adenomyomatöz Hiperplazide Prostat Hacmi ve PSA Düzeyi ile Connexin 32 Illişkisi}

\author{
[iD Havva Erdem¹, id Abdullah Çırakoğlu², iD Erdal Benli2, iD Soner Çankaya3 \\ 1 Ordu University Faculty of Medicine, Department of Pathology, Ordu, Turkiye \\ 2Ordu University Faculty of Medicine, Department of Urology, Ordu, Turkiye \\ 3 Ondokuz Mayıs University Faculty of Medicine, Department of Biostatistics and Medical Informatics, Samsun, Turkiye
}

\section{What's known on the subject? and What does the study add?}

Prostate cancer (PC) is the second most common cancer in men in the world. PC is associated with many parameters. Connexins may also be prognostic parameters in this study, we aimed to evaluate Cx32 expression in prostatic adenocarcinomas and adenomyomatous hyperplasia. In addition, age, prostate-specific antigen level, prostate volume, Gleason score (and grade group) were also evaluated.

\begin{abstract}
Objective: Prostate cancer (PC) is the second most common cancer in men in the world. PC is associated with many parameters. Connexins may also be prognostic parameters in this study, we aimed to evaluate Cx32 expression in prostatic adenocarcinomas (PCa) and adenomyomatous hyperplasia (AH). In addition, age, prostate-specific antigen (PSA) level, prostate volume (PV), Gleason score (GS) (and grade group) were also evaluated.

Materials and Methods: This study was conducted on a total of 48 cases including $23 \mathrm{PCa}$ and $25 \mathrm{AH}$.

Prostate samples were stained with Cx32 antibody by immunohistochemical method. Age, GS (and grade group), PV and PSA values were recorded. Cx32 staining intensity of the cases were evaluated statistically with these parameters.

Results: The age range of patients with $\mathrm{PCa}$ and $\mathrm{AH}$ was $46-83$ years and $50-86$ years, respectively.

The PV in PCa patients and AH patients ranged from 21 to $135 \mathrm{~mL}$ and from 36 to $110 \mathrm{~mL}$, respectively.

The PSA value in PCa and AH patients ranged from 1 to $1122 \mathrm{ng} / \mathrm{mL}$ and from 1 to $16 \mathrm{ng} / \mathrm{mL}$, respectively.

In cases with PCa, no statistically significant correlation was observed between GS and age and intensity of CX32 staining ( $p=0.523$ and $p=0.093$, respectively). However, the mean age of $\mathrm{Cx} 32$-positive patients was higher than that of $\mathrm{Cx32-negative} \mathrm{patients} \mathrm{(72.62} \mathrm{vs} \mathrm{67.03).} \mathrm{The} \mathrm{rate} \mathrm{of} \mathrm{Cx} 32$ positive PCa cases was higher than that of $\mathrm{AH}$ cases (39.1\% vs $24 \%)$.

Conclusion: Cx32 expression tended to increase with age. However, no significant relationship was found between PCa and AH and Cx32.

Keywords: Prostatic adenocarcinomas, Adenomyomatous hyperplasia, Prostate-specific antigen, Prostate volume

\section{Öz}

Amaç: Prostat kanseri, dünyada erkeklerde en sık görülen ikinci kanserdir. Prostat kanseri birçok parametreyle ilişkilidir. Belki de konnexinler de prognostik parametre olabilirler. Bu çalışmada, prostat adenokarsinomu (PCa) ve adenomyomatöz hiperplazide (AH) Cx32 ekspresyonunu değerlendirmeyi amaçladık. Ayrıca yaş, prostat spesifik antijen (PSA) düzeyi, prostat hacmi (PV), Gleason skoru (GS) (ve grade grubu) da değerlendirildi. Gereç ve Yöntem: Bu çalışma 23 PCa ve 25 AH dahil toplam 48 olgu üzerinde gerçekleştirildi. Prostat örnekleri immünohistokimyasal yöntemle Cx32 antikoru ile boyandı. Yaş, GS, PV ve PSA değerleri kaydedildi. Olguların Cx32 boyama şiddeti bu parametrelerle istatistiksel olarak değerlendirildi. Bulgular: PCa ve AH hastalarının yaş aralığı sırasıyla 46-83 ve 50-86 idi. PCa hastalarında ve AH hastalarında PV sırasıyla 21 ila 135 mL ve 36 ila 110 $\mathrm{mL}$ arasında değişmekteydi. PCa ve AH hastalarındaki PSA değeri sırasıyla 1 ila $1122 \mathrm{ng} / \mathrm{mL}$ ve 1 ila $16 \mathrm{ng} / \mathrm{mL}$ arasında değişmekteydi. PCa olgularında Cx32 boyama şiddetinin GS ve yaş arasında istatistiksel olarak anlamlı bir ilişki gözlenmemiştir (sırasıyla $p=0,523$ ve $p=0,093$ ). Bununla birlikte, $C x 32$ pozitif olguların ortalama yaşı, Cx32 negatif olguların yaşından daha yüksekti $(72,62$ vs 67,03). Yüzde olarak, Cx32 pozitif PCa olgu sayısı AH olgu sayısından daha yüksekti $(\% 39,1 / \% 24)$.
\end{abstract}

Correspondence: Havva Erdem MD, Ordu University Faculty of Medicine, Department of Pathology, Ordu, Turkiye Phone: +90 5305970961 E-mail: drhavvaerdem@gmail.com ORCID-ID: orcid.org/0000-0002-3074-0240 Received: 20.06.2019 Accepted: 17.11 .2019

Cite this article as: Erdem H, Cırakoğlu A, Benli E, Cankaya S. Association of Connexin 32 with Prostate Volume and PSA Level in Prostatic Adenocarcinoma and Adenomyomatous Hyperplasia. Journal of Urological Surgery, 2020;7(2):103-108

๑Copyright 2020 by the Association of Urological Surgery / Journal of Urological Surgery published by Galenos Publishing House. 
Sonuç: Cx32 ekspresyonu yaşla birlikte artma eğilimindedir. Bununla birlikte, PCa ile AH ve Cx32 arasında anlamlı bir ilişki bulunamadı. Anahtar Kelimeler: Prostat adenokarsinomları, Adenomyomatöz hiperplazi, PSA, Prostat hacmi.

\section{Introduction}

Prostate cancer (PC) is the second most commonly occurring cancer and the fifth leading cause of death in men worldwide $(1,2)$.

There is great variability in the biological behavior and metastatic potential of prostatic adenocarcinomas (PCa). The effectiveness of treatment depends on age, medical parameters, stage, grade and available medical facilities $(1,2,3)$.

Prostate-specific antigen (PSA) testing and digital rectal examination are recommended for the detection of PCa $(4,5)$. Serum PSA level is the most commonly used marker to detect this cancer in the general population $(4,5)$. However, PSA is prostate-specific but not disease-specific. As a result, it is not sufficient alone in PCa screening $(4,5)$.

Practical and feasible PC staging and classification will guide treatment options and help determine the prognosis of PC $(6,7,8)$. PSA level, pathological tumor [the extent of primary tumor (pT)] level and Gleason score (GS) are very important prognostic factors. However, these parameters may not be sufficient for diagnosis and follow-up $(6,7,8,9,10)$.

Gap junction (GJ) channel proteins include pannexines, innexins and connexins $(C x)(11,12,13)$. The classification of $C x$ was based on two systems: the first is the molecular weight in the cDNA sequence. So, Cx32 and Cx43 correspond to the molecular weights of $32 \mathrm{kDa}$ and $43 \mathrm{kDa}(14)$. The second is based on the sequence similarity and length of the cytoplasmic domain of the Cx (classifying them into $\alpha, \beta$, and $\gamma$ subgroups) (15). GJs play an important role in cell-to-cell transition controls. GJs provide intercellular communication through water-soluble molecules. The major cellular function is the control of homeostasis. They play an important role in several functions such as reproduction, differentiation and migration. In addition, they also play an important role in homeostasis, tumor suppression and other cellular functions. Homeostatic imbalance may lead to a variety of diseases including malignant tumors $(11,12,13)$.

Cx32 expression is observed in acinar cells of exocrine glands such as prostate and pancreas (16).

The aim of this study was to evaluate the relationship of Cx32 with prostate volume (PV), PSA, GS and grade group in PCa and adenomyomatous hyperplasia $(\mathrm{AH})$.

\section{Materials and Methods}

This study is a retrospective study. The study protocol was reviewed and approved by the Ordu University Ethics Committee with the approval number 2016/43. This study was conducted on a total of 48 paraffin-embedded prostate samples, which were histopathologically diagnosed at the Department of Pathology between 2014 and 2015. The samples consisted of 23 PCa and $25 \mathrm{AH}$. Pathological materials of cases diagnosed with PCa were radical prostatectomy and tru-cut biopsy specimens. The GS and grade group distribution of the samples were as follows; 2 cases: GS 4 (grade group 1), 11 cases: GS 6 (grade group 1), 2 cases: GS 3+4 (grade group 2), 1 case: GS 4+3 (grade group 3), 4 cases: GS 8 (grade group 4), and 3 cases: GS 9 (grade group 5). Age, GS, PV and PSA values of the patients were evaluated. These parameters were compared with Cx32 staining. Paraffinembedded prostate samples were cut at $3 \mu \mathrm{m}$ thickness. These sections were immunostained with $\mathrm{C} \times 32$ antibody.

\section{Immunohistochemistry}

The sections were kept at $60{ }^{\circ} \mathrm{C}$ for 1 hour, then xylol and alcohol steps were applied. The sections were incubated in a $3 \%$ hydrogen peroxide solution for 10 minutes, then, washed for 5 minutes in distilled water. Antigen was retrieved through retrieval step. Immunohistochemical staining was performed using the avidin-biotin complex technique. The antigen was washed in phosphate buffered saline after the retrieval protocol. Primary antibody Cx32 (dilution ratio 1:200) was applied. The sections were rinsed in 3-amino-9-ethylcarbazole and chromogen substrate (10 minutes), washed with water, stained with hematoxylin (3 minutes) and covered with mounting medium, respectively.

The stained sections were examined with a Nikon Eclipse Niu microscope and photos were taken.

Cx32 scoring was evaluated semi-quantitatively. The evaluation was made as follows; no staining (score 0), weak (score 1), strong (score 2) (Figure 1,2) (17). In addition, gland and stromal cells were evaluated.

In order to obtain statistically significant results, the cases showing weak and strong staining were evaluated as the group showing positive staining, and in this way, two groups were formed as negative and positive groups. 


\section{Statistical Analysis}

A chi-square test was used to investigate the relationship between $\mathrm{C} \times 32$ staining results (negative, positive) and biopsy diagnoses $(\mathrm{PCa}, \mathrm{AH})$ after pathological examination of the samples taken from patients in the study.

In addition, the independent samples t-test, Fisher-FreemanHalton exact test and the Mann-Whitney $U$ test $(p<0.05)$ were applied to reveal the relationship between $\mathrm{C} \times 32$ staining results and biopsy diagnosis.

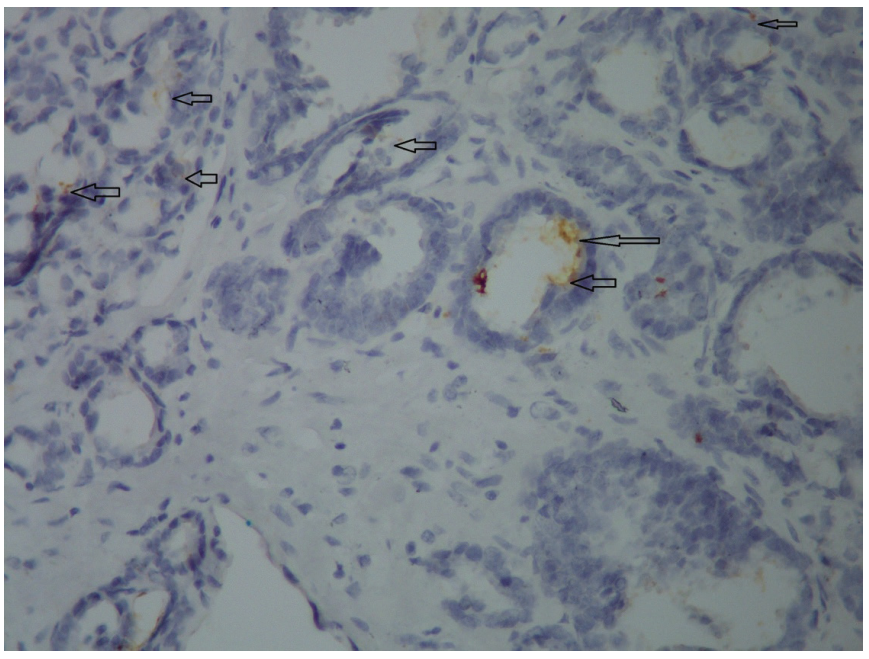

Figure 1. Cx32 expression (strong degree) was observed in malignant glands. The staining showed apical, membranous ( $\mathrm{C} \times 32 \times 400)$

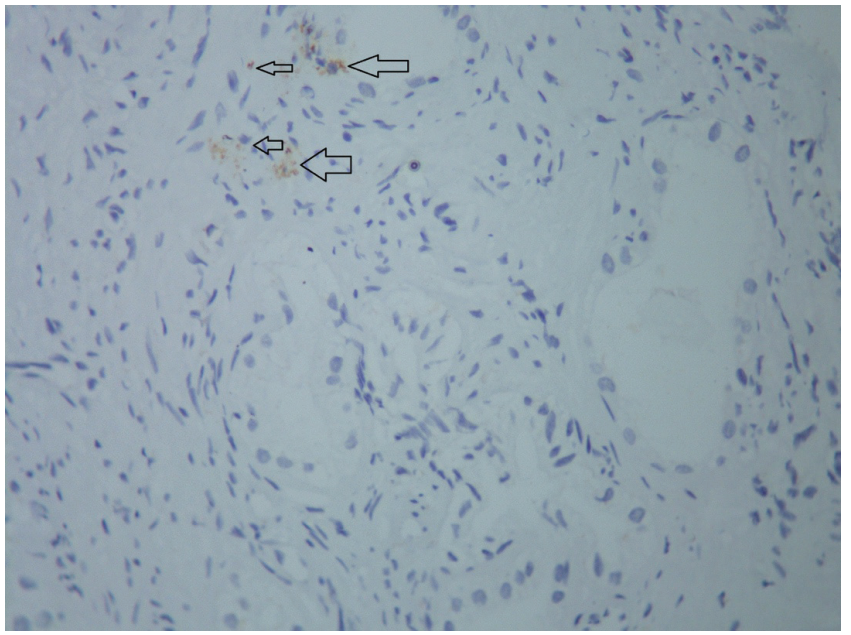

Figure 2. Cx32 expression (middle degree) was observed in adenomyomatous hyperplasia. The staining showed apical, membranous (Cx32 x 200)
Mann-Whitney U test was used to evaluate patient age, PSA and PV. All statistical calculations were made using the SPSS v.19.0 program.

\section{Results}

Descriptive statistics including age, PSA and PV measurements in 48 samples ( $\mathrm{PCa}$ and $\mathrm{AH}$ ) are shown in Table 1,2. The age of the $\mathrm{PCa}$ and $\mathrm{AH}$ patients ranged from 46 to 83 years and 50 to 86 years, respectively. The age distribution of the $\mathrm{PCa}$ patients is as follows: 6 cases were under 65 years of age and 16 cases were over 65 years old. The PV of the PCa patients and $\mathrm{AH}$ patients ranged from 21 to $135 \mathrm{~mL}$ (determined via ultrasonographic evaluation as follows: width $x$ height $x$ length $x$ 0.52) and from 36 to $110 \mathrm{~mL}$, respectively. The PSA value in PCa and $\mathrm{AH}$ patients ranged from 1 to $1122 \mathrm{ng} / \mathrm{mL}$ and from 1 to 16 $\mathrm{ng} / \mathrm{mL}$, respectively. The mean age of the $\mathrm{PCa}$ and $\mathrm{AH}$ patients was $70.3 \pm 1061$ and $68.12 \pm 10.08$ years, respectively. The mean PSA value was $112.00(\min =1, \max =1122 \mathrm{ng} / \mathrm{mL})$ and $5.98 \pm 4.14$, respectively. The mean PV was $60.78 \pm 31.81$ and $59.00 \pm 21.73$, respectively. The relationship of age with PSA and PV was evaluated in $\mathrm{AH}$ and $\mathrm{PCa}$ groups and no significant correlation was found ( $p=0.468, p=0.197$ and $p=0.820$, respectively). No significant relationship of $\mathrm{C} \times 32$ expression with $\mathrm{PCa}$ and $\mathrm{AH}$ was found ( $p=0.656$, Fisher-Freeman-Halton exact test) (Table 3 ).

No significant relationship was found between GS and Cx32 expression in PCa group ( $r=-0.140$ and $p=0.523$, Spearman's correlation coefficient).

Cx32 expression was evaluated in all patients with $\mathrm{PCa}$. The mean age of the $\mathrm{C} \times 32$-positive and -negative patients was 72.62 and 67.03 years, respectively. The mean age of Cx32-positive

Table 2. Comparison of AH and PCa groups with age, PSA and prostate volume

\begin{tabular}{|l|l|l|l|l|}
\hline & n & Age & PSA $^{* *}$ & PV* \\
\cline { 3 - 5 } & & Mean \\
\hline PCa groups & 23 & 70.30 & 112.00 & 60.78 \\
\hline AH groups & 25 & 68.12 & 5.98 & 59.00 \\
\hline p & & 0.468 & 0.197 & 0.820 \\
\hline $\begin{array}{l}\text { *: Independent samples t-test; **: Mann-Whitney U test, PV: Prostate volume, PSA: } \\
\text { Prostate-specific antigen, PCa: Prostatic adenocarcinomas, AH: Adenomyomatous } \\
\text { hyperplasia }\end{array}$ \\
\hline
\end{tabular}

Table 1. Values for age, PSA and prostate volume measurements

\begin{tabular}{|c|c|c|c|c|c|c|c|}
\hline \multirow{2}{*}{\multicolumn{2}{|c|}{\begin{tabular}{|l|l} 
& $n$
\end{tabular}}} & \multirow[t]{2}{*}{ Mean } & \multirow[t]{2}{*}{ Min } & \multirow[t]{2}{*}{ Max } & \multicolumn{3}{|l|}{ Percentiles } \\
\hline & & & & & $25^{\text {th }}$ percentile & Median & $75^{\text {th }}$ percentile \\
\hline Age & 48 & 69.1667 & 46.00 & 86.00 & 60.2500 & 68.0000 & 79.7500 \\
\hline PV & 48 & 59.8542 & 21.00 & 135.00 & 44.2500 & 52.0000 & 67.0000 \\
\hline
\end{tabular}


patients was higher than -negative patients (72.62 vs. 67.03). The rate of $\mathrm{C} \times 32$-positive $\mathrm{PCa}$ cases was higher than that of $\mathrm{AH}$ cases $(39.1 \%$ vs. $24 \%)$. There was no statistically significant relationship between $\mathrm{C} \times 32$ expression and age $(\mathrm{p}=0.093)$ (Table 4).

\begin{tabular}{|c|c|c|c|c|c|}
\hline \multirow{2}{*}{\multicolumn{2}{|c|}{ Count }} & \multicolumn{2}{|c|}{ AH groups } & \multicolumn{2}{|c|}{ PCa groups } \\
\hline & & $\%$ & Count & $\%$ & \\
\hline \multirow[t]{3}{*}{ Cx32 } & negative & 19 & 76.0 & 14 & 60.9 \\
\hline & mild & 5 & 20.0 & 8 & 34.8 \\
\hline & strong & 1 & 4.0 & 1 & 4.3 \\
\hline \multicolumn{2}{|l|}{ Total } & 25 & - & 23 & $p=0.656$ \\
\hline
\end{tabular}

Table 4. The distribution of Cx32 results according to age

\begin{tabular}{|l|l|l|l|l|l|}
\hline \multicolumn{2}{|l|}{ Cx32 } & $\mathbf{n}$ & Mean & \multicolumn{2}{|l|}{ Std. Deviation } \\
\hline \multirow{2}{*}{ Age } & negative & 33 & 67.03 & 9.95 & $\mathrm{p}=0.093$ \\
\cline { 2 - 5 } & positive & 15 & 72.62 & 9.87 & \\
\hline
\end{tabular}

\section{Discussion}

There are many studies on PSA levels, rate of positive biopsies, lymph node metastasis, positivity of surgical margins, extracapsular enlargement and seminal vesicle invasion, GS, and biochemical recurrence. These studies have tried to reveal the risk of biochemical recurrence, especially after radical prostatectomy $(18,19,20,21,22,23)$. GJs or $C x$ are space junctions composed of protein subunits. GJs have an important role in cellular communication, growth, differentiation and carcinogenesis. GJ dysfunction has been reported to be associated with various cancers and diseases $(21,22,23,24)$.

Jee et al. (24) reported that $C \times 32$ was expressed at intercellular contact points in normal cells and showed punctate intercellular and intracyloplasmic staining in cancer cells. It was also found that the frequency of altered Cx32 expression in adenocarcinoma was significantly higher compared to that in normal mouse stomach. The expression pattern of $\mathrm{C} \times 32$ in mouse gastric cancer model was similar to that in human. $\mathrm{C} \times 32$ was mainly expressed in the cytoplasm of epithelial cells in the mucus metaplasia of mouse stomach. There was also an inverse correlation between $\mathrm{C} \times 32$ expression and cell proliferation in mouse tumors. In terms of mRNA levels, there was no difference between normal and cancerous tissues (24).

Fujimoto et al. (25) found that Cx32 suppressed the Src-Stat3vascular epithelial growth factor (VEGF) signaling and thus had a tumor suppressor effect against a metastatic renal cell carcinoma (RCC) cell line (Caki-1 cell) in vivo. They suggested that Cx32 was a promising molecular target for potential new cancer therapy due to the effects on angiogenesis. They reported a close relationship between Cx32 expression level, $\mathrm{Src} / \mathrm{Stat} 3$ signaling activation and VEGF production in invasive and metastatic RCC tissues (25).

Xu et al. (26) assessed the association between $\mathrm{C} \times 43$ expression and clinicopathologic features of $\mathrm{PCa}$ and biochemical recurrence after radical prostatectomy. They found that $\mathrm{C} \times 43$ protein significantly decreased or disappeared in $\mathrm{PCa}$ compared to $\mathrm{AH}$ tissues. It was reported that reduced $\mathrm{Cx} 43$ expression was associated with advanced clinicopathological features (26).

Saladino et al. (27) evaluated Cx43, Cx32 and Cx26 expressions in non-tumorigenic and tumorigenic human prostate epithelial cells. In their study, there was an inverse relationship between the expression levels of $\mathrm{C} \times 43$ and $\mathrm{C} \times 32$. They reported that $\mathrm{C} \times 43$ was largely expressed in non-tumorigenic cells while $\mathrm{C} \times 32$ was predominantly expressed in tumorigenic cells (27).

In their study investigating $\mathrm{C} \times 26, \mathrm{C} \times 32$ and $\mathrm{C} \times 43$ expressions in paraffin samples obtained from patients with $\mathrm{PCa}$ and $\mathrm{AH}, \mathrm{Hu}$ et al. (28) found positive expressions of $\mathrm{C} \times 32$ in $78.3 \%$ of $\mathrm{AH}$ and $61.3 \%$ of PCa samples ( $p>0.05$ ). In this study, positive $\mathrm{Cx} 32$ staining was observed in stromal cells and glandular epithelium (Figure 1,2).

Staining was seen in cytoplasmic and cytoplasmic membrane. The degree of staining was mild and did not differ significantly in terms of benign and malign differentiation. In this study, Cx32 staining was positive in 24\% of $\mathrm{AH}$ patients and $40 \%$ of $\mathrm{PCa}$ patients. It was observed that the $\mathrm{C} \times 32$ staining rate was higher in the PCa group compared to the AH group. However, there was no statistically significant relationship between $\mathrm{C} \times 32$ expression and age $(p=0.093)$. In a more recent study, it was shown that in men with benign prostatic hyperplasia $(n=1859)$, the PV increased from $27.7 \mathrm{~mL}$ in the $40-49$ age group to 52.3 $\mathrm{mL}$ in the 70-80 age group (29).

In this study, the average $P V$ was $59 \mathrm{~mL}$ and the average age was 68.12 years in AH group. When compared with the literature, the reason for the high PV may be related to the older patients in this study.

Stephan et al. (30) reported that the mean PV in BPH patients was larger than in PCa group and there was a positive correlation between PV and total PSA. In this study, there was no significant difference in PV between $\mathrm{PCa}$ and $\mathrm{AH}$ groups. It was noticed that there was no significant correlation between PSA and PV. Cx32 expression exhibited no correlation with PV and PSA level in the PCa and AH groups. Serum PSA level may increase for many reasons. For example, the PSA level may increase in hyperplastic growth of prostate tissues, prostate manipulation, urinary retention, sexual activity, inflammation and cancer 
(31). In this study, PSA values were higher in patients with PCa than in those with $\mathrm{AH}(112 ; 5.98$ respectively). In this study, it was noticed that PV and PSA did not increase at the same rate. Patients with PCa are mostly over 65 years of age and $\mathrm{PCa}$ is rare in men younger than 50 years (32). In this study, 6 cases were under 65 years old and the others were over 65 years of age. While the prevalence of PCa in young men (aged $<50$ years) was $1 \%$ in the 1970s, recenty, it has increased to $20-30 \%$ (32). In this study, 1 patient with PCa was 46 years old and 6 were under 65 years old and the others were over 65 years of age.

The average age of the $\mathrm{Cx} 32$-negative patients was 66.06 years. The mean age of $\mathrm{AH}$ and $\mathrm{PCa}$ patients was 68.12 and 70.3 years, respectively. Cx32-negative cases were younger than $\mathrm{C} \times 32$ positive cases. However, loss of Cx32 expression was observed in both $\mathrm{AH}$ and $\mathrm{PCa}$ patients and no statistically significant difference was detected.

In this study, there was no correlation between $\mathrm{Cx} 32$, diagnosis (PCa and $\mathrm{AH}$ ) and PSA.

\section{Conclusion}

Cx32 expression increases with age. No significant correlation was found between Cx32 expression and GS, PV, PSA, PCa and $\mathrm{AH}$. Further large-scale studies are warranted.

\section{Ethics}

Ethics Committee Approval: The study protocol was reviewed and approved by the Ordu University Ethics Committee with the approval number 2016/43.

Informed Consent: Retrospective study.

Peer-review: Externally peer-reviewed.

\section{Authorship Contributions}

Concept: H.E., Design: H.E., Data Collection or Processing: H.E., Analysis or Interpretation: S.Ç., Literature Search: H.E., Writing: H.E.

Conflict of Interest: No conflict of interest was declared by the authors.

Financial Disclosure: The authors declared that this study received no financial support.

\section{References}

1. Kamangar F, Dores GM, Anderson WF. Patterns of cancer incidence, mortality and prevalence across five continents: defining priorities to reduce cancer disparities in different geographic regions of the world. J Clin Oncol 2006;24::2137-2150.

2. Bray F, Ferlay J, Soerjomataram I, Siegel RL, Torre LA, Jemal A. Global cancer statistics 2018: Globocan estimates of incidence and mortality worldwide for 36 cancers in 185 countries. CA Cancer J Clin 2018;68:394-424.
3. Hong R, Lim SC. Pathological significance of connexin 26 expression in colorectal adenocarcinoma. Oncology Reports 2008;19:913-919.

4. Aslan $Y$, Tekdogan U, Tuncel A, Uzun MB, Karabulut E, Atan A. Serum dehydroepiandrosterone sulfate usage for early detection of prostate cancer in men with serum prostate specific antigen level between 2.5 and $4.0 \mathrm{ng} / \mathrm{mL}$ : a pilot study. Turk J Med Sci 2008;38:399-404.

5. Catalona WJ, Smith DS, Ratliff TL, Dodds KM, Coplen DE, Yuan JJ, Petros $\mathrm{JA}$, Andriole GL. Measurement of prostate-specific antigen in serum as a screening test for prostate cancer. N Engl J Med 1991;324:1156-1161.

6. Epstein JI, Allsbrook WC Jr, Amin MB, Egevad LL, ISUP Grading Committee. The 2005 International Society of Urological Pathology (ISUP) Consensus Conference on Gleason Grading of Prostatic Carcinoma. Am J Surg Pathol 2005;29:1228-1242.

7. D'Amico AV, Whittington $R$, Malkowicz $S B$, Wu $Y H$, Chen $M$, Art $M$ Tomaszewski JE, Wein A. Combination of the preoperative PSA level, biopsy gleason score, percentage of positive biopsies, and MRI T-stage to predict early PSA failure in men with clinically localized prostate cancer. Urology 2000;55:572-577.

8. Tsivian M, Sun L, Mouraviev V, Madden JF, Mayes JM, Moul JW, Polascik TJ. Changes in Gleason score grading and their effect in predicting outcome after radical prostatectomy. Urology 2009;74:1090-1093.

9. Budäus $L$, Isbarn $H$, Eichelberg $C$, Lughezzani $G$, Sun $M$, Perrotte $P$, Chun FK, Salomon G, Steuber T, Köllermann J, Sauter G, Ahyai SA, Zacharias $M_{\text {, }}$ Fisch M, Schlomm T, Haese A, Heinzer $H$, Huland H, Montorsi $F$, Graefen M, Karakiewicz Pl. Biochemical recurrence after radical prostatectomy: multiplicative interaction between surgical margin status and pathological stage. J Urol 2010;184:1341-1346.

10. Yen MR, Saier MH Jr. Gap junctional proteins of animals: the innexin/ pannexin superfamily. Prog Biophys Mol Biol 2007;94:5-14.

11. Willecke $K$, Eiberger J, Degen J, Eckardt D, Romualdi $A$, Güldenagel $M_{1}$ Deutsch U, Söhl G. Structural and functional diversity of connexin genes in the mouse and human genome. Biol Chem 2002;383:725-737.

12. Scemes E, Spray DC, Meda P. Connexins, pannexins, innexins: novel roles of "hemi-channels". Pflugers Arch 2009;457:1207-1226.

13. Beyer EC, Paul DL, Goodenough DA. Connexin43: A protein from rat heart homologous to a gap junction protein from liver. J Cell Biol 1987;105:26212629.

14. Hervé JC, Derangeon M, Sarrouilhe D, Giepmans BN, Bourmeyster N. Gap junctional channels are parts of multiprotein complexes. Biochim Biophys Acta 2012;1818:1844-1865

15. Eiberger J, Degen J, Romualdi A, Deutsch U, Willecke K, Söhl G. Connexin genes in the mouse and human genome. Cell Commun Adhes 2001;8:163165.

16. Bosco D, Haefliger JA, Meda P. Connexins: key mediators of endocrine function. Physiol Rev 2011;91:1393-1445.

17. Poyet C, Buser L, Roudnicky F, Detmar M, Hermanns T, Mannhard D, Höhn A, Rüschoff J, Zhong Q, Sulser T, Moch H, Wild PJ. Connexin 43 expression predicts poor progression-free survival in patients with non-muscle invasive urothelial bladder cancer. Journal of Clinical Pathology 2015;68:819-824.

18. Saraon $\mathrm{P}$, Jarvi $\mathrm{K}$, Diamandis EP. Molecular alterations during progression of prostate cancer to androgen independence. Clin Chem 2011;57:1366-1375

19. Deng FM, Donin NM, Pe Benito R, Melamed J, Le Nobin J, Zhou M, Ma S, Wang J, Lepor H. Size-adjusted Quantitative Gleason Score as a Predictor of Biochemical Recurrence after Radical Prostatectomy. Eur Urol 2016;70:248-253.

20. Bai PD, Hu MB, Xu H, Zhu WH, Hu JM, Yang T, Jiang HW, Ding O. Body mass index is associated with higher Gleason score and biochemical recurrence risk following radical prostatectomy in Chinese men: a retrospective cohort study and meta-analysis. World J Surg Oncol 2015;13:311.

21. Kang HW, Jung HD, Lee JY, Kwon JK, Jeh SU, Cho KS, Ham WS, Choi YD. Prostate-specific antigen density predicts favorable pathology and 
biochemical recurrence in patients with intermediate-risk prostate cancer. Asian J Androl 2016;18:480-484.

22. Ma HQ, Liang XT, Zhao JJ, Wang $H$, Sun JC, Chen YB, Pan K, Xia JC. Decreased expression of Neurensin-2 correlates with poor prognosis in hepatocellular carcinoma. World journal of gastroenterology 2009;15:4844-4848.

23. Soloway MS, Soloway CT, Eldefrawy A, Acosta K, Kava B, Manoharan M. Careful selection and close monitoring of low-risk prostate cancer patients on active surveillance minimizes the need for treatment. Eur Urol 2010;58:831-835.

24. Jee $\mathrm{H}, \mathrm{Nam} \mathrm{KT}$, Kwon HJ, Han SU, Kim DY. Altered expression and localization of connexin 32 in human and murine gastric carcinogenesis. Dig Dis Sci 2011;56:1323-1332.

25. Fujimoto $E_{\text {, Sato }} H_{\text {, Shirai }} S_{\text {, Nagashima }} Y_{\text {, Fukumoto }} K_{\text {, Hagiwara }} H_{1}$ Negishi E, Ueno K, Omori Y, Yamasaki H, Hagiwara K, Yano T. Connexin-32 as a tumor suppressor gene in a metastatic renal cell carcinoma cell line. Oncogene 2005;24:3684-3690.

26. Xu N, Chen HJ, Chen $S H$, Xue XY, Chen $H$, Zheng QS, Wei Y, Li XD, Huang JB, Cai $H$, Sun XL. Reduced Connexin 43 expression is associated with tumo malignant behaviors and biochemical recurrence-free survival of prostate cancer. Oncotarget 2016;7:67476-67484.
27. Saladino F, Carruba G, Quader ST, Amoroso M, Di Cristina A, Webber M, Castagnetta LA. Connexin expression in nonneoplastic human prostate epithelial cells. Ann N Y Acad Sci 2002;963:213-217.

28. Hu LP, Liu ZX, Bai ZM, Tan S. Expressions of Cx26, Cx32 and Cx43 in prostate cancer and their implications. Zhonghua Nan Ke Xue 2014;20:23-29.

29. Mochtar CA, Kiemeney LA, van Riemsdijk MM, Barnett GS, Laguna MP, Debruyne FM, de la Rosette JJ. Prostate-specific antigen as an estimator of prostate volume in the management of patients with symptomatic benign prostatic hyperplasia. Eur Urol 2003:44:695-700.

30. Stephan C, Stroebel G, Heinau M, Lenz A, Roemer A, Lein M, Schnorr D, Loening SA, Jung K. The ratio of prostate-specific antigen (PSA) to prostate volume (PSA density) as a parameter to improve the detection of prostate carcinoma in PSA values in the range of $<4 \mathrm{ng} / \mathrm{mL}$. Cancer 2005;104:9931003.

31. Carter HB, Partin AW. Diagnosis and staging of prostate cancer. Chapter 88 In: Walsh PC, Retik AB, Vaughan ED, Wein AJ, editors. Campbell's Urology. 8th edition, Philiadelphia: Saunders; 2002, pp 3055-3079.

32. Hussein S, Satturwar S, Van der Kwast T. Young-age prostate cancer. J Clin Pathol 2015;68:511-515. 